Proceedings

\title{
Economic Evaluation of the Feasibility When Installing a Biogas Plant for Treatment of Slaughterhouse Wastewater ${ }^{+}$
}

\author{
I.C. Gato, R.M. Panizio * , L.F.C. Calado and P.S.D. Brito \\ VALORIZA, Research Center for Endogenous Resource Valorization, Polytechnic Institute of Portalegre, \\ 7300-110 Portalegre, Portugal; ilda.gato@ipportalegre.pt (I.C.G.); luis.calado@ipportalegre.pt (L.F.C.C.); \\ pbrito@ipportalegre.pt (P.S.D.B.) \\ * Correspondence: rpanizio@ipportalegre.pt \\ + Presented at the 5th Ibero-American Congress on Entrepreneurship, Energy, Environment and \\ Technology-CIEEMAT, Portalegre, Portugal, 11-13 September 2019.
}

Published: 26 December 2019

\begin{abstract}
The process of anaerobic digestion generates biogas filled with $\mathrm{CH}_{4}$, this gas may be harnessed to produce electricity, heating and even used to produce biofuel. An evaluation of the economic viability of the implementation of a digestion unit was done, by applying this principle at a slaughterhouse in Alto Alentejo. The project was scaled to process about $151.000 \mathrm{~m}^{3} / \mathrm{year}$, it has an estimated cost of over 337.000 euros. The evaluation was made with an investment from the company itself, investment programs and with recycling of the heat, obtaining a return on investment period of 10, 6 and 2 years respectively.
\end{abstract}

Keywords: economic evaluation; anaerobic digestion; biogas; electric and thermal energy

\section{Introduction}

With the technologic advancements that occurred in the last century, the recycling and the energetic valorisation of waste, became a viable solution to the problems related with dumping, problems of environmental pollution of the soil and water and problems related with the limitation of non-renewable energetic resources. Coinciding even with the spreading awareness over the limitation of non-renewable energetic resources like fossil fuel [1].

Nowadays the thermochemical and biologic processes are being studied as a method of minimizing the effects of pollution and production of alternative energy sources. Among those resources the biologic process of decomposition of the organic matter of waste to produce biogas becomes viable for the hard to treat effluents because of their high organic charge $[2,3]$.

The effluents prevenient of the animal slaughterhouses, hold high quantities of fat, protein, lipids and organic matters, becoming a viable source to produce biogas and use of effluents from the digestion as fertilizers with applications in agriculture as a way for recovery of nutrients. However, they are considered hard digestion wastes, mainly because they contain a high charge of protein that releases ammonia, that can work as a mean of inhibition for the anaerobic microorganisms [4].

A slaughterhouse produces on average $0.9 \mathrm{~m}^{3}$ of effluent per processed animal [5,6]. After anaerobic digestion experiments, an economic feasibility evaluation was performed for the installation of an autonomous anaerobic digestion unit [7].

\section{Case Study}

The study was based on slaughterhouse located in the region of Alto Alentejo, in the city of Sousel. The unit receives on average 700 animals per day. The water used on the process originates 
from de water supply network and from two water holes. The water from the treatment station is repurposed for the washing of trucks.

The economic evaluation was based on the energetic recovery of this waste through the installation of an autonomous unit of biogas production through the anaerobic digestion process. On a circular economy perspective, incorporating this waste in new value chains as production of electrical and thermal energy and also utilizing the sludge resulting from the process for agricultural purposes.

With the help of the tool from IAPMEI, three different scenarios were proposed. The first one being the use of biogas produced for generating electrical energy for sale with the support of programs of national financing. The second scenario proposed uses the electrical energy and thermal energy generated for self-consumption and the use of the company resources for the installation of the unit and the third scenario combines the use of electrical and thermal energy with the support of programs of national financing. Taking in consideration the initial investments and the variables previously shown, it was calculated the different periods of return on investment.

\section{Mass Balance and Energy}

The estimate volume of biogas produced per day was calculated with base on the studies previously made and with data supplied from the company. The effluent from slaughterhouses is characterized for having a COD between 580 and $3750 \mathrm{mg} / \mathrm{L}$ and about $0.63 \%$ of dissolved solids [5,7].

Assuming $0.9 \mathrm{~m}^{3}$ of effluent per animal and that each gram of COD degraded at $35^{\circ} \mathrm{C}$ produces $0.35 \mathrm{~m}^{3}$ of $\mathrm{CH}_{4}$ with a time of residence of 20 days, occurring a reduction of $90 \%$ on COD, $10 \%$ between the entry and the exit of COD are accumulated as biomass and $90 \%$ are converted to methane [8]. Based on the studies it was then calculated a daily quantity of effluent produced of $630 \mathrm{~m}^{3}$, obtaining then a daily production of $1218 \mathrm{~m}^{3}$ of biogas. Supposing that, the total of solids prevenient from effluents and biomass produced with origin on degraded COD produces $217 \mathrm{~kg}$ of sludge/day.

The economic viability for the installation of a digestion unit was calculated based on the balance of mass and energy. The numbers of annual biogas production, the numbers of converted electrical and thermal energy and the quantity of sludges produced are present in Table 1.

The electrical and thermal production is made possible by the CHP (combined heat and power) unit in which $30 \%$ of the energy contained in consumed biogas its transformed in electrical energy and $60 \%$ in thermal energy.

The size of the engine for biogas utilization is calculated based on the methane content, the lower heating value of methane, and the biogas engine efficiency, calculated as follows in Equation (1).

$$
\text { E GasEngine }(\mathrm{kW})=(\mathrm{B} \times 55 \% \times 36 \times 0.3 \times 0.2778) / 7000
$$

where $55 \%$ is the volumetric methane content in the biogas, 36 is the lower heating value $\left(\mathrm{MJ} / \mathrm{m}^{3}\right.$ methane) of methane gas, 0.3 is the average thermal efficiency of gas engine to convert methane heating value to electricity energy, 0.2778 is the conversion factor of $\mathrm{MJ}$ to $\mathrm{kWh}$ and 7000 is the operational hours of the gas engine in a year considering the recommended top-end overhaul maintenance for the CHP unit.

Considering both electricity and thermal efficiencies of gas-engine CHP, the net annual electricity $(\mathrm{kWh} /$ year) and the heat $(\mathrm{kWh})$ generation from biogas plant for sale can, be calculated as follows in Equations (2) and (3).

$$
\begin{gathered}
\text { E Electricity }=B \times 55 \% \times 36 \times 0.3 \times 0.2778 \times(100-9) \% \\
\text { E Heat }=B \times 55 \% \times 36 \times 0.6 \times 0.2778 \times(100-30) \%
\end{gathered}
$$

where 9 and 30 are the percentage of electricity and heat, respectively, that are used internally by the biogas plant, and are thus not available for external uses and 0.3 and 0.6 are set as electricity and thermal efficiencies, respectively. 
Table 1. Annual production of biogas, electric and liquid thermal energy in the anaerobic digestion unit and annual amount of effluent received and annual sludge production.

\begin{tabular}{ccc}
\hline Parameter & Unity & Value \\
\hline Slaughterhouse Wastewater & $\mathrm{m}^{3} /$ year & 151200 \\
Biogas Production & $\left(\mathrm{m}^{3} /\right.$ year $)$ & 292263 \\
Electric Energy & $(\mathrm{kWh} /$ year $)$ & 438868 \\
Thermal Energy & $(\mathrm{kWh} /$ year $)$ & 675181 \\
Sludge Produced & $(\mathrm{kg} /$ year $)$ & 51983 \\
\hline
\end{tabular}

\section{Economic Evaluation and Sensitivity Analysis}

Based on the mass and energy balance, it was possible to do an economic analysis to determine the viability of the installation of the digestion unit. All components where determined in function of de $\mathrm{m}^{3}$ of effluent produced per year based on the number of animals killed and/or in the production of biogas $\mathrm{m}^{3} /$ year.

According with the Portaria number 32/2018 on January 23rd, the tariff of reference on produced electricity originating from biogas is fixated at $85.5 € / \mathrm{MWh}$ [9]. According with the obtained values for the useful production of electrical energy with a production of $438.9 \mathrm{MWh}, 37,523 €$ /year is obtained. The digested sludges can be commercialized for $0.02 € / \mathrm{kg}$ [10].

The economic balance supports itself in the values achieved earlier for the costs and recipes. For the annual economic balance, monetary flux, a depreciation of $20 \%$ the equipment suffers was considered. An annual inflation of $0 \%$ was considered, since there is no prediction of any alterations on prices in the duration of the project. The interest tax was set at $2 \%$.

The sensibility analysis has as an objective measuring the sensibility of the viability indicators to determined fundamental variables to the analysis and thus measuring its own degree of uncertainty and the risks of the obtained conclusions. It's usual to establish more than one scenario. In this present study 3 scenarios were established. In Table 2 the data related to Net Present Value (NPV), Internal Rentability Rate (IRR) and an Investment Payback (IPP) for each scenario was presented.

Table 2. Sensitivity Analysis.

\begin{tabular}{lc}
\hline \multicolumn{1}{c}{ Scenarios } & Variations \\
\hline & NPV $-14391 €$ \\
1-Approval of the application for the project and selling of electric energy produced. & IRR $-7.34 \%$ \\
& IPP -10 years \\
\hline 2-Production of electric and thermal energy for self-consumption of the & NPV $-279553 €$ \\
slaughterhouse. & IRR $-21.7 \%$ \\
\hline 3-Approval of the application for the project and production of electric and thermal & IPP -6 years \\
energy for self-consumption of the slaughterhouse. & IRR $-52.79 \%$ \\
\end{tabular}

In Scenario 1, the allocation of the subsidy worth 192,900 $€$ will diminish the investment costs, making the project viable. However, the period until return on investment is 10 years long. In scenario 2, the use of thermal and electrical energy useful for self-consumption, reveals an impact in the Net Present Value, increases the Internal Rentability Rate, and diminishes the Return on Investment Period to 6 years. Of all the scenarios, Scenarios 3 it's the most favourable-The Net Present Value would be $433,397 €$ with one profitability rate of $52.79 \%$ and one investment payback period of 2 years. 


\section{Conclusions}

The financial viability analysis of the implementation of an anaerobic digestion unit for the appreciation of the effluents originating on a slaughterhouse through a unit of cogeneration was made.

The Cogeneration allows for a globally improvement on the efficiency of conversion of fuel to energy, being and advantage when there's a purpose for the thermal energy produced. From the Sensibility Analysis it is possible to conclude that the lofty investment in the Anaerobic Digestion Unit it's a contributing factor to the financial Income presented. Therefore, one hypothesis to turn this waste appreciation viable would be diminishing the initial investment costs, through subsidies or through the diminishing of the equipment costs consisting on the Anaerobic Digestion Units.

Resorting to subsidies on the investment of the biodigestion unit, the project presents economic viability with a Net Present Value of $14391 €$, although with a long period until return on investment with a hefty 10 year wait and a low Internal Rentability Rate of $7.4 \%$, as such, it's not an attractive investment. If the project is realized by the slaughterhouse, taking in account the self-consumption electrical energy and useful thermal energy produced, we see an increase in the Net Present Value (279 $553 €$ ), a shortened Period Until Return on Investment (6 years) and an increase on the Rentability Rate of $21.7 \%$. An application to the financing program, will increase the Net Present Value to 433 $397 €$, and the Rentability tax to $52.79 \%$ and the period until return on investment will be reduced to 2 years.

In short, biogas technology integrates the rural development, the protection of the environment and climate and the consequent diminishing of emissions, the production of renewable energy, and it is predicted that it will have, in Portugal, a more relevant role than the one it has today, in the development of local, regional and global energy markets.

\section{References}

1. Deng, Y.; Xu, J.; Liu, Y.; Mancl, K. Biogas as a sustainable energy source in China: Regional development strategy application and decision making. Renew. Sustain. Energy Rev. 2014, 35, 294-303.

2. Wang, S.; Jena, U.; Das, K.C. Biomethane production potential of slaughterhouse waste in the United States. Energy Convers. Manag. 2018, 173, 143-157.

3. Alfa, I.M.; Dahunsi, S.O.; Iorhemen, O.T.; Okafor, C.C.; Ajayi, S.A. Comparative evaluation of biogas production from Poultry droppings, Cow dung and Lemon grass. Bioresour. Technol. 2014, 157, $270-277$.

4. Hejnfelt, A.; Angelidaki, I. Anaerobic digestion of slaughterhouse by-products. Biomass Bioenergy 2009, 33, 1046-1054.

5. Widiasa, B.I.N.; Sunarso, S.J. Study on Slaughterhouse Wastes Potency and Characteristic for Biogas Production. Int. J. Waste Resour. 2015, 1, 4-7.

6. de Arruda, V.C.M. Tratamento Anaeróbio de Efluentes Gerados em Matadouros Bovinos. Master Thesis, Universidade Federal de Pernambuco, Recife, Brazil, 2004.

7. Panizio, R.M.; Filipe, L.; Gonçalo, C.; Paulo, L.; Duque, S. Potential of Biogas Production in Anaerobic Codigestion of Opuntia ficus - Indica and Slaughterhouse Wastes. In Waste and Biomass Valorization; Springer: Berlin, Germany, 2019.

8. Jain, S.; Jain, S.; Wolf, I.T.; Lee, J.; Tong, Y.W. A comprehensive review on operating parameters and different pretreatment methodologies for anaerobic digestion of municipal solid waste. Renew. Sustain. Energy Rev. 2015, 52, 142-154.

9. da República, D. 1.A Série-No. 16-23 de Janeiro de 2018. In Portaria no 32/2018 de 23 de Janeiro; Diário da República: Portugal, 2018.

10. Valenti, F.; Porto, S.M.C.; Dale, B.E.; Liao, W. Spatial analysis of feedstock supply and logistics to establish regional biogas power generation: A case study in the region of Sicily. Renew. Sustain. Energy Rev. 2018, 97, $50-63$. 